\title{
Links between Patagonian Ice Sheet fluctuations and Antarctic dust variability during the last glacial period (MIS 4-2)
}

\author{
Jérôme Kaiser ${ }^{\mathrm{a}, *}$, Frank Lamy ${ }^{\mathrm{b}}$ \\ ${ }^{a}$ Helmholtz-Zentrum Potsdam, Deutsches GeoForschungsZentrum (GFZ), Telegrafenberg, 14473 Potsdam, Germany \\ ${ }^{\mathrm{b}}$ Alfred Wegener Institut für Polar- und Meeresforschung, Am Alten Hafen 26, 27568 Bremerhaven, Germany
}

\section{A R T I C L E I N F O}

Article history:

Received 16 October 2009

Received in revised form

2 March 2010

Accepted 4 March 2010

\begin{abstract}
A B S T R A C T
Antarctic and Greenland ice-core records reveal large fluctuations of dust input on both orbital and millennial time-scales with potential global climate implications. At least during glacial periods, the Antarctic dust fluctuations appear to be largely controlled by environmental changes in southern South America. We compare dust flux records from two Antarctic ice-cores to variations in the composition of the terrigenous supply at ODP Site 1233 located off southern Chile and known to record fluctuations in the extent of the northern part of the Patagonian ice-sheet (NPIS) during the last glacial period (Marine Isotope Stage, MIS, 4 to 2). Within age uncertainties, millennial-scale glacial advances (retreats) of the NPIS correlate to Antarctic dust maxima (minima). In turn, NPIS fluctuations were closely related to offshore sea surface temperature (SST) changes. This pattern suggests a causal link involving changes in temperature, in rock flour availability, in latitudinal extensions of the westerly winds and in foehn winds in the southern Pampas and Patagonia. We further suggest that the long-term trend of dust accumulation is partly linked to the sea-level related changes in the size if the Patagonian source area due to the particular morphology of the Argentine shelf. We suggest that sea-level drops at the beginning of MIS 4 and MIS 2 were important for long-term dust increases, while changes in the Patagonian dust source regions primarily control the early dust decrease during the MIS 4/3 transition and Termination 1.
\end{abstract}

(C) 2010 Elsevier Ltd. All rights reserved.

\section{Introduction}

Atmospheric dust can affect climate in different ways. Absorption and scattering of incoming solar radiation and outgoing planetary radiation modify the radiative balance of the atmosphere (Harrison et al., 2001; Penner et al., 2001). As a result, both a warming and a cooling at the earth surface can occur depending on the characteristics of the dust (e.g. concentration, particle size) and external variables such as albedo and surface temperature (Harrison et al., 2001). Dust particles can also act as cloud or ice condensation nuclei, modifying cloud properties and thus climate (DeMott et al., 2003; Mahowald and Kiehl, 2003). Atmospheric chemistry is affected by dust concerning for example rainwater acidity, abundance of tropospheric ozone and the nitrogen and sulphur cycles (Harrison et al., 2001). Finally, dust contains iron and other nutrients, which may modify terrestrial and marine biogeochemistry, and thus the uptake of carbon dioxide (Martin, 1990; Okin et al., 2004).

\footnotetext{
* Corresponding author. Present address: LOCEAN, UMR 7159 CNRS, Université Pierre et Marie Curie, 4 place Jussieu, 75005 Paris, France, Tel.: +33144274866; fax: +33 144273805 .

E-mail address: jerome.kaiser@locean-ipsl.upmc.fr (J. Kaiser).
}

Ice core records from Greenland and Antarctica show that high latitude dust deposition was the property of the Earth system which underwent the largest glacial-interglacial changes (Broecker, 2000) with up to thirtyfold higher values during glacial periods than during interglacial periods (Steffensen, 1997; Ruth et al., 2003; EPICA community members, 2004; Lambert et al., 2008). Low latitude marine sediment records suggest 3-4 times higher dust deposition during glacial times (Rea, 1994; Winckler et al., 2008). The causes of changes in the atmospheric dust concentrations during glacial times are still unclear. Four main factors have been invoked to explain higher glacial dust loadings and deposition rates (Harrison et al., 2001; Ridgwell, 2002; Fischer et al., 2007a). First, increased wind speeds allow more dust to be entrained and carried to high latitudes. Second, reduced hydrological cycle and vegetation cover extend arid dust source areas and allow dust to remain longer in the atmosphere. Third, lowered sea-level enlarges potential dust source areas on the continental shelves. Fourth, a reduced glacial atmospheric washout during transport prolongs the atmospheric lifetime of mineral dust aerosol and largely facilitates transport of dust to Antarctica (Lambert et al., 2008).

Using strontium and neodymium isotopic signatures of Antarctic dust, sediment, and soil samples, Grousset et al. (1992) 
and Basile et al. (1997) have demonstrated that during glacial periods the dust contained in the eastern Antarctic Dome $C$ and Vostok ice cores has a dominant and constant Patagonian origin. Delmonte et al. (2004) found similar results based on samples from EPICA Dome C (EDC) ice core and an extended amount of continental samples. While a partial overlap exists among South America, New Zealand and Antarctic isotope field, the dominant contribution are the regions of Patagonia and the southern Pampas (i.e. south of $37^{\circ} \mathrm{S}$ ) (Smith et al., 2003; Delmonte et al., 2004). Furthermore, the isotopic signature of last glacial clays and silts from southern Patagonia is consistent with values of glacial dust from Antarctic ice cores (Sugden et al., 2009) and He isotopic signatures of mineral dust in Antarctica suggest an increased weathering flux in Patagonia during glacial times (Winckler and Fischer, 2009). Finally, recent studies suggest that a second dust source end-member may be located on the high subtropical Andean plateaus (Puna-Altiplano area, $10^{\circ}-26^{\circ} \mathrm{S}$ ) (Gaiero, 2007; Delmonte et al., 2010).

Sugden et al. (2009) could show that dust peaks in Antarctica coincide with periods in Patagonia when rivers fed by glacial meltwater deposited sediment onto outwash plains, while no dust peaks were noted when the glaciers terminated into proglacial lakes. Therefore, glacier fluctuations in Patagonia may have acted as an on/off switch for Antarctic dust deposition. Our study based on ODP Site 1233 located offshore southern Chile provides additional evidences that dust variability during the last glacial was strongly influenced by Patagonian ice-sheet (PIS) glacial advances and rock flour production, and by the northward extension of the southern westerly winds (SWW) and the intensification of the foehn wind on the lee side of the southern Andes.

\section{Investigation area}

Southern South America is the only significant landmass covering nearly the complete latitudinal range of the SWW belt. The SWW result from the thermal gradient and atmospheric pressure difference between cold air masses over Antarctica and the warmer air and water masses in the subtropical regions (e.g. Cerveny, 1998) (Fig. 1A). On the annual mean, the SWW are centred around $50^{\circ} \mathrm{S}$ and the associated storm tracks (a quasi-permanent sequence of cyclonic waves migrating eastward; Reijmer et al., 2002) bring cold and humid air masses which lose their humidity by orographic lift over the southern Andes. This results in heavy rainfalls feeding the modern Northern and Southern Patagonian Icefields. By crossing the Andes, the SWW are accelerated and result in dry and relatively warm foehn winds that produce an orographic desert on the Andean lee side (Iriondo, 2000). The most arid region located between $37^{\circ} \mathrm{S}$ and $48^{\circ} \mathrm{S}$ covers northern Patagonia and the southern Pampas and is a major dust source area today (Prospero et al., 2002) (Fig. 1B). The surface geology in this area is dominated by glacial, glacio-fluvial and volcanic sediments derived from the Andes. Present-day dust transport mechanisms from Patagonia to Antarctica involve aeolian dust deflation in Patagonia and the southern Pampas, dust rising up into the atmosphere by the cyclonic activity linked to the SWW, and eastsoutheast advection into the circumpolar vortex spiralling towards Antarctica (Basile et al., 1997; Iriondo, 2000). Furthermore, the extreme dryness of the air allows picking up a large amount of dust (Iriondo, 2000).

ODP Site $1233\left(41^{\circ} 00^{\prime} \mathrm{S}, 74^{\circ} 27^{\prime} \mathrm{W}\right)$ is located $\sim 38 \mathrm{~km}$ offshore at 838 meter water depth on the upper continental slope off southern Chile (Mix et al., 2003) (Fig. 1C). As shown by our previous studies (Lamy et al., 2004; Kaiser et al., 2007), the location of Site 1233 allows tracing variability of NPIS extensions and retreats during the last glacial and their relationship with offshore SSTs.

\section{Material and methods}

\subsection{Chronology}

We are considering here only the glacial interval from 18 to 70 kyr BP recorded at ODP Site 1233 that covers 25 to 135 meter composite depth (mcd). For the upper part, we use radiocarbon dates as previously published by Lamy et al. (2007) (Table 1). Further downcore, we re-calibrated the previously published dates (Lamy et al., 2004) using the Fairbanks0107 calibration curve (http://radiocarbon.ldeo.columbia.edu; Fairbanks et al., 2005) and added two new radiocarbon datings (Table 1 ). A constant reservoir age correction of $0.4 \mathrm{kyr}$ has been applied to all radiocarbon dates (for discussion see Lamy et al., 2004). The record of the Laschamp magnetic field excursion gives an independent date at $41.25 \mathrm{kyr}$ BP (Svensson et al., 2006). The oldest part of Site 1233 has been dated by tuning the SST record to the temperature-dependant, atmospheric $\delta^{18} \mathrm{O}$ record of the Antarctic Byrd ice core (Kaiser et al., 2005).

\subsection{Alkenone-based SST reconstruction}

While most of the alkenone-based SST record from Site 1233 has been published previously (Lamy et al., 2004, 2007; Kaiser et al., 2005), we have increased the resolution to $\sim 0.07 \mathrm{kyr}$ between 47.9 and $64.8 \mathrm{mcd}$ (i.e. $\sim 30$ to $41 \mathrm{kyr} \mathrm{BP}$ ). The method used for $\mathrm{C}_{37}$ alkenones measurement is described elsewhere (Kaiser et al., 2005; Lamy et al., 2007). We applied the Prahl et al. (1988) calibration curve for conversion of the $\mathrm{UK}^{\prime}{ }_{37}$ into temperature values $\left[\mathrm{T}\left({ }^{\circ} \mathrm{C}\right)=\right.$ $\left.\left(\mathrm{UK}^{\prime}{ }_{37}-0.039\right) / 0.034\right]$. The method uncertainty was estimated to be $\pm 0.3^{\circ} \mathrm{C}$. Mollenhauer et al. (2005) have shown that alkenones can be older than co-occurring foraminifera off southern Chile. However, for reasons thoroughly discussed in Lamy et al. (2007) (such as the absence of sediment re-suspension/re-deposition cycles and the negligible admixture of older material on the reconstructed SST) and because of the strong synchrony between air temperature changes as recorded in Antarctic ice cores and the alkenone-based SST record in the radiocarbon-dated interval of Site 1233 (40-0 kyr) (Kaiser et al., 2005; Lamy et al., 2007), we assume that our SST record is not substantially affected by age offsets between the fine fraction containing alkenones and the coarse fraction containing the foraminifera that have been used for dating.

\subsection{Fe and Ti measurements}

The iron (Fe) and titanium (Ti) relative concentrations within the bulk sediment were measured by XRF (X-ray fluorescence) core scanning. The Fe record has been previously published in Lamy et al. (2004) and Kaiser et al. (2007). The time-resolution of both records is $\sim 0.005 \mathrm{kyr}$ between 18 and $70 \mathrm{kyr}$. In order to obtain a resolution similar to the ice core records shown here and to improve the signal-to-noise ratio due to high frequency variability, both records were smoothed by applying a 100-pt moving average to the raw data (not shown).

\section{Results and discussion}

\subsection{Patagonian Ice Sheet glacial activity and Antarctic dust variability}

In our previous studies (Lamy et al., 2004; Kaiser et al., 2007), we showed that the relative concentration of $\mathrm{Fe}$ in the continental margin sediments at Site 1233 is a faithful proxy for the bulk terrestrial input from the Andean hinterland. This interpretation is reinforced by the strong similarities between the Fe and Ti records, 

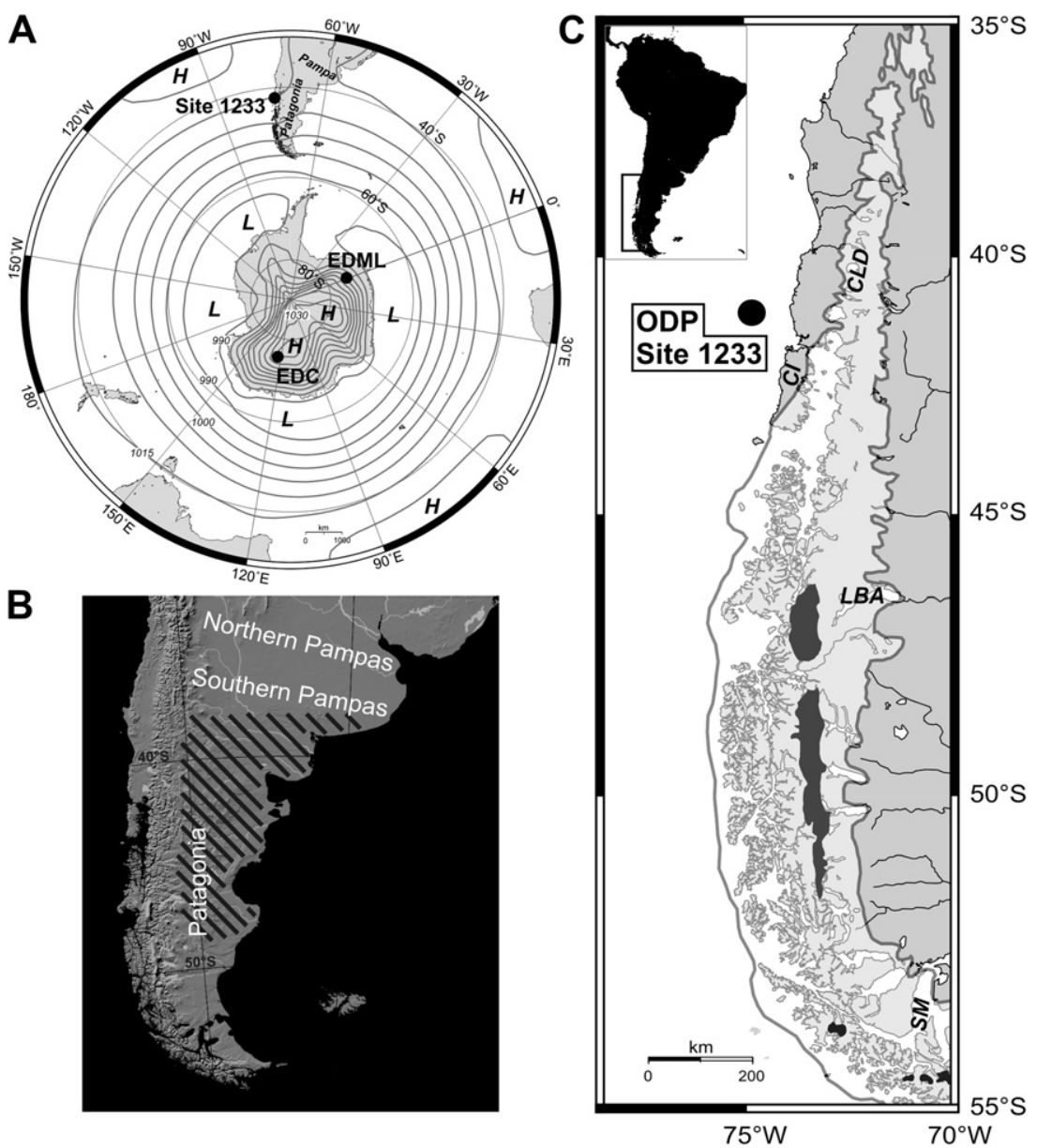

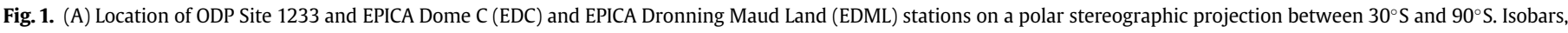

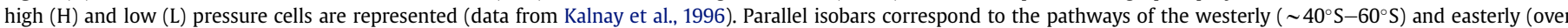

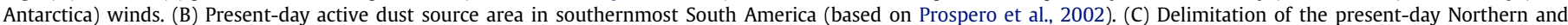

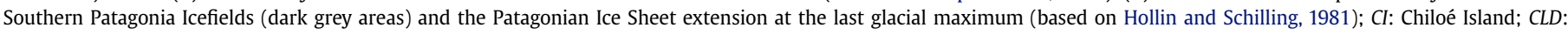
Chilean Lake District; LBA: Lago Buenos Aires; SM: Strait of Magellan.

as Ti can be considered as quasi-entirely lithogenous largely unaffected by early diagenetic alteration processes (Murray and Leinen, 1993; Mora and Martinez, 2005). During the last glacial, the NPIS (north of $\sim 48^{\circ} \mathrm{S}$ ) was located very proximal to our site (Fig. 1C) and the terrigenous input changes were primarily driven by changes in the glacio-fluviatile sediment supply to the ocean. During the coldest SST intervals of late MIS 3 and MIS 2, maxima in both Fe and $\mathrm{Ti}$ records are corresponding within age uncertainties to NPIS glacier advances as reconstructed on the adjacent land (Chiloé Island and the Chilean Lake District region; Fig. 1C) (Denton et al., 1999) (Fig. 2A-D). This correspondence suggests that $\mathrm{Fe}$ and $\mathrm{Ti}$ records from Site 1233 are ultimately recording NPIS advances (Fe and $\mathrm{Ti}$ maxima) and retreats (Fe and $\mathrm{Ti}$ minima) during the last glacial period. During early MIS 3, the terrestrial record of NPIS advances becomes sparse. However, there are some indications that the NPIS extent was much more restricted during early MIS 3 (Denton et al., 1999) consistent with substantially higher average SSTs relatively to MIS 4, late MIS 3 and MIS 2 (Fig. 2). In addition, it is possible that part of the glacial sediment was trapped in lakes resulting from the retreat of the NPIS after its maximum extent during MIS 4 and/or that the Fe input was partly controlled by rainfall during this time-interval (Kaiser et al., 2007).

To test a possible link between NPIS glacier activity and Antarctic dust, we compare our Site $1233 \mathrm{Fe}$ and Ti records with two dust flux records based on non-sea-salt calcium $\left(\mathrm{nssCa}^{2+}\right)$, one from EDC ice core $\left(75^{\circ} \mathrm{S}, 123^{\circ} \mathrm{E}\right)$ and one from EPICA Dronning Maud Land ice core (EDML; $75^{\circ} \mathrm{S}, 0^{\circ} \mathrm{E}$ ) (Fischer et al., 2007b), which is located in the downstream air mass trajectories from the Patagonian dust source (Figs. $1 \mathrm{~A}$ and $2 \mathrm{E}-\mathrm{F}$ ). Strong similarities exist between the two ice-core dust records and dust maxima (minima) correlate to Fe and Ti maxima (minima), suggesting a strong relationship between Antarctic dust and NPIS glacier variability during the last glacial at millennial to multi-millennial timescales. The link is less clear during early MIS 3 (62-50 kyr BP), when the terrigenous input may be trapped in proglacial lakes and/or partly controlled by rainfall as suggested above. The dust maxima generally correspond to Fe and Ti maxima within $\leq 1.3 \mathrm{kyr}$, which is satisfactory considering the uncertainties of the age models [up to $0.8 \mathrm{kyr}$ for Site 1233 (Kaiser et al., 2007) and up to $1.5 \mathrm{kyr}$ for both the EDC3 (Parrenin et al., 2007) and the EDML1 age models (Ruth et al., 2007; Severi et al., 2007)].

We consider that NPIS glacial advances and retreats as recorded at Site 1233 are representative for all PIS glaciers. However, glacier maxima as reconstructed on land at different latitudes are not synchronous during late MIS 3 and MIS 2 (Fig. 2B). In the Strait of Magellan ( $\sim 53^{\circ} \mathrm{S}$; Fig. $\left.1 \mathrm{C}\right)$, the advance representing the last glacial maximum occurred between $\sim 31$ and $23 \mathrm{kyr}$ and culminated at ca 25.2-23.1 kyr BP, followed by a less extensive advance sometime before $\sim 22-20 \mathrm{kyr} \mathrm{BP}$, as inferred by ${ }^{14} \mathrm{C}$ radiocarbon dates (McCulloch et al., 2005). A more recent study based on ${ }^{10} \mathrm{Be}$ 
Table 1

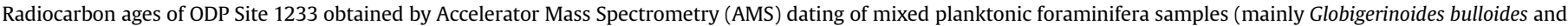

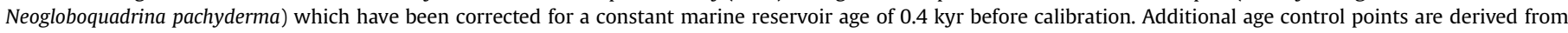

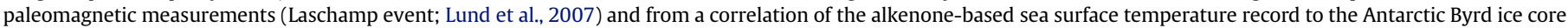
(Kaiser et al., 2005).

\begin{tabular}{|c|c|c|c|c|c|c|}
\hline $\begin{array}{l}\text { Core depth } \\
\text { (mcd) }\end{array}$ & $\begin{array}{l}{ }^{14} \text { C AMS age } \\
\text { (kyr BP) }\end{array}$ & $\begin{array}{l} \pm \text { Error } \\
\text { (kyr) }\end{array}$ & $\begin{array}{l}\text { Calibrated age } \\
\text { (cal. kyr BP) }\end{array}$ & $\begin{array}{l} \pm \text { Error } \\
\text { (kyr) }\end{array}$ & $\begin{array}{l}\text { Calibration } \\
\text { method }\end{array}$ & Published in \\
\hline 25.1 & 14.02 & 0.11 & 17.35 & 0.07 & Calpal SFCP $2005^{\mathrm{a}}$ & Lamy et al., 2007 \\
\hline 27.97 & 15.35 & 0.07 & 18.73 & 0.05 & INTCALO $^{\mathrm{b}}$ & Lamy et al., 2007 \\
\hline 29.81 & 16.67 & 0.11 & 19.77 & 0.14 & INTCALO $^{\mathrm{b}}$ & Lamy et al., 2007 \\
\hline 31.47 & 17.41 & 0.09 & 20.54 & 0.1 & INTCALO $^{\mathrm{b}}$ & Lamy et al., 2007 \\
\hline 33.51 & 18.12 & 0.13 & 21.57 & 0.24 & INTCALO $^{\mathrm{b}}$ & Lamy et al., 2007 \\
\hline 36.56 & 19.34 & 0.14 & 23.00 & 0.26 & INTCALO $^{\mathrm{b}}$ & Lamy et al., 2007 \\
\hline 39.5 & 20.68 & 0.15 & 24.90 & 0.3 & INTCALO $^{\mathrm{b}}$ & Lamy et al., 2007 \\
\hline 41.17 & 21.44 & 0.24 & 25.35 & 0.41 & INTCALO4 $^{\mathrm{b}}$ & This study \\
\hline 43.72 & 22.93 & 0.23 & 27.07 & 0.29 & Fairbanks $2005^{\mathrm{c}}$ & updated from Lamy et al., 2004 \\
\hline 45.53 & 23.88 & 0.17 & 28.15 & 0.24 & Fairbanks $2005^{c}$ & This study \\
\hline 47.25 & 25.28 & 0.24 & 29.85 & 0.38 & Fairbanks $2005^{c}$ & updated from Lamy et al., 2004 \\
\hline 49.11 & 26.1 & 0.29 & 30.90 & 0.34 & Fairbanks $2005^{\mathrm{c}}$ & updated from Lamy et al., 2004 \\
\hline 50.72 & 26.52 & 0.30 & 31.36 & 0.35 & Fairbanks $2005^{c}$ & updated from Lamy et al., 2004 \\
\hline 55.02 & 29.03 & 0.39 & 34.02 & 0.43 & Fairbanks $2005^{\mathrm{c}}$ & updated from Lamy et al., 2004 \\
\hline 59.03 & 32.19 & 0.58 & 37.17 & 0.61 & Fairbanks $2005^{c}$ & updated from Lamy et al., 2004 \\
\hline 62.5 & 34.48 & 0.75 & 39.45 & 0.75 & Fairbanks $2005^{c}$ & updated from Lamy et al., 2004 \\
\hline 64.81 & 35.77 & 0.79 & 40.67 & 0.75 & Fairbanks $2005^{c}$ & updated from Lamy et al., 2004 \\
\hline 67.8 & & & 41.25 & & Laschamp event & updated from Lamy et al., 2004 \\
\hline 74.62 & & & 43.01 & & & Kaiser et al., $2005^{\mathrm{d}}$ \\
\hline 81.25 & & & 47.31 & & & Kaiser et al., $2005^{d}$ \\
\hline 88.26 & & & 51.65 & & & Kaiser et al., $2005^{d}$ \\
\hline 96.66 & & & 54.76 & & & Kaiser et al., $2005^{d}$ \\
\hline 101.55 & & & 56.95 & & & Kaiser et al., $2005^{\mathrm{d}}$ \\
\hline 111.36 & & & 59.31 & & & Kaiser et al., $2005^{d}$ \\
\hline 121.17 & & & 63.70 & & & Kaiser et al., $2005^{\mathrm{d}}$ \\
\hline 129.56 & & & 67.84 & & & Kaiser et al., $2005^{\mathrm{d}}$ \\
\hline 133.75 & & & 69.21 & & & Kaiser et al., $2005^{\mathrm{d}}$ \\
\hline
\end{tabular}

"CalPal SFCP 2005" calibration curve (www.calpal.de)

b "INTCAL04" calibration curve (Reimer et al., 2004) (http://intcal.qub.ac.uk/calib/).

c "Fairbanks0107" calibration curve (Fairbanks et al., 2005) (http://radiocarbon.ldeo.columbia.edu/).

d Correlation to the $\delta^{18} \mathrm{O}$ record of the Byrd ice-core on GISP2 timescale (Blunier and Brook, 2001).

chronology places the glacier maximum at $24.6 \mathrm{kyr}$ and minor advances at 20.4 and $18.5 \mathrm{kyr}$ BP (Kaplan et al., 2008). A recent study located on the eastern side of the Andes at $\sim 46^{\circ} \mathrm{S}$ (Lago Buenos Aires) suggests that ice was at its maximum extent around $22.7 \mathrm{kyr}$ BP, while minor glacier advances occurred at 21.4 and 19.9 kyr BP (Douglass et al., 2006). In the Chilean Lake District ( $\left.41^{\circ} \mathrm{S}\right)$, the available records indicate glacier advances around 33.5 and $30.5 \mathrm{kyr} \mathrm{BP}$, a major advance at $\sim 27 \mathrm{kyr} \mathrm{BP}$, followed by less extensive advances at $\sim 25,21.5$ and $19 \mathrm{kyr}$ BP (Denton et al., 1999). On the one hand, age uncertainties may explain part of the asynchrony. For example, the ice maximum dated around $23 \mathrm{kyr}$ BP at Lago Buenos Aires is statistically indistinguishable from the $\sim 25$ kyr BP event in the Strait of Magellan (Kaplan et al., 2008). On the other hand, asynchrony may be related to differences in climate and/or ice dynamics. Douglass et al. (2006) suggest that the deep water in the lake basin of Lago Buenos Aires may have delayed ice advances, while glacial advances in the Chilean Lake District were facilitated by shallower water bodies. At a larger scale, modelled PIS snowlines are most sensitive to air temperature changes in regions of high precipitation $\left(46^{\circ}-50^{\circ} \mathrm{S}\right)$, and most sensitive to precipitation changes in regions of low precipitation (south of $50^{\circ} \mathrm{S}$ and north of $40^{\circ} \mathrm{S}$ ) (Kerr and Sugden, 1994). In a modelling study of the PIS deglaciation, the NPIS is much more sensitive to climate forcing than the southern PIS (south of $\sim 48^{\circ} \mathrm{S}$ ) and reacts rapidly to relatively small changes in both temperature and precipitation (Hulton et al., 2002). Furthermore, in their modelling study of the NPIS, Hubbard et al. (2005) have shown that a weaker lowering of the equilibrium line altitude (ELA), which is a function of both air temperature and rainfall changes, results in glacier advances on the western part of the NPIS, while a stronger ELA lowering is necessary for glacier advances in its eastern part. Furthermore, during the deglaciation, the PIS collapse occurs first in its western seaward sector, which was occupied by tidewater glaciers, and slightly later across the entire NPIS. Therefore, while latitudinal and longitudinal asynchronies probably existed beyond dating uncertainties, not only the concord between Site $1233 \mathrm{Fe}$ and Ti maxima and PIS advances at $\sim 27-25, \sim 22$ and $\sim 19 \mathrm{kyr} \mathrm{BP}$, but also the strong similarities between the Fe and Ti records and Antarctic dust during the last glacial period suggest that NPIS advances and retreats are representative for the entire PIS fluctuations at millennial to multimillennial timescales.

\subsection{The role of the southern westerly winds}

Two main factors can change the amount of dust during the last glacial period as recorded in Antarctic ice cores: (1) changes in dust production and (2) variations in dust deflation and transport. We suggest here that these two factors are closely related to the location of the SWW in the southeast Pacific region. Studies based on $\mathrm{nssCa}^{2+}$ and sea-salt $\mathrm{Na}^{+}$fluxes of EDC and EDML ice cores provide evidences that the transport time for dust from Patagonia to Antarctica has not changed strongly between the last glacial and the Holocene (Fischer et al., 2007b). As well, most of general circulation models suggest modest changes in atmospheric transport (Mahowald et al., 1999; Werner et al., 2002; Krinner and Genthon, 2003), or changes which are too small to account for the large dust variability as recorded in ice cores (Röthlisberger et al., 2002). However, the northward expansion of Antarctic seaice (Crosta et al., 2004; Gersonde et al., 2005) and evidences from paleoenvironmental reconstructions in southern South America (Markgraf et al., 1992; Lamy et al., 1999; Moreno et al., 1999; McCulloch et al., 2000; Stuut and Lamy, 2004; Kaiser et al., 2005, 


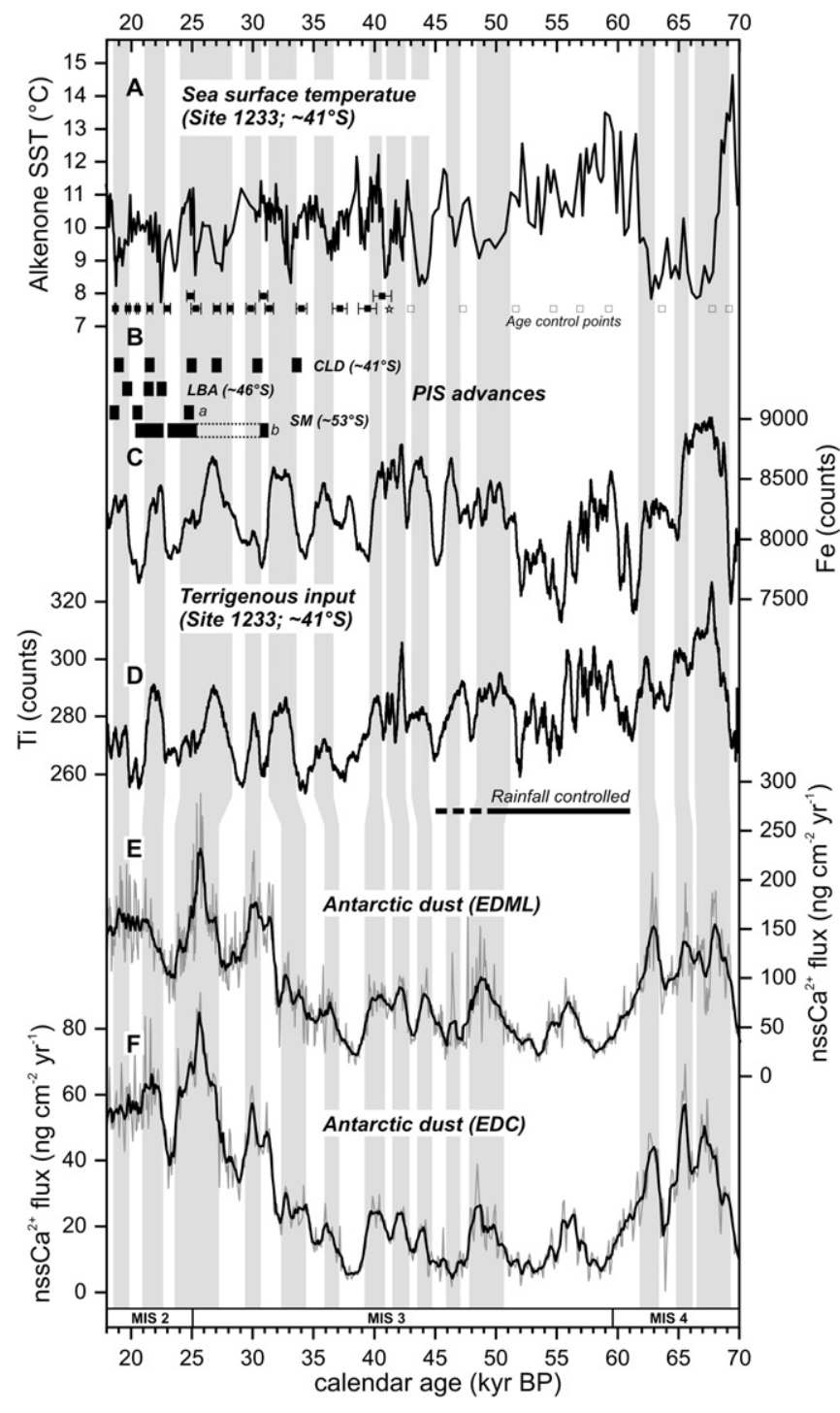

Fig. 2. Relationships between sea surface temperature changes in the southeast Pacific, Patagonian Ice Sheet activity and Antarctic dust variability. A) Sea surface temperature record from ODP Site 1233. B) Patagonian Ice Sheet advances as reconstructed in the Chilean Lake District (CLD; Denton et al., 1999), in Lago Buenos Aires (LBA; Douglass et al., 2006) and in the Strait of Magellan (SM; $a$ : Kaplan et al., 2008; $b$ : McCulloch et al., 2005). C-D) Titanium (Ti) and iron (Fe) relative concentrations from Site 1233 (100-pts moving average), respectively. Age control points of Site 1233 are shown. E-F) Non-sea-salt calcium (nssCa2+) flux from EPICA Dronning Maud Land (EDML) (row data and 10-pts moving average) and EPICA Dome C (EDC) (row data and 5-pts moving average) ice cores (Fischer et al., 2007b), respectively.

2008) suggest a northward extension of the SWW during the last glacial period. Together with a mean temperature lowered by 6-7 ${ }^{\circ} \mathrm{C}$ (Denton et al., 1999; Moreno et al., 1999; Lamy et al., 2004), northward extended SWW would increase humidity and thus the growth of the PIS (Hulton et al., 2002).

The resulting advances of PIS glaciers would increase the total erosion rate and thus enhance the supply of fluvio-glacial outwash material (rock flour debris) in eastern Patagonia, while a calving margin was present along most of the western side of the PIS (Fig. 1C). This glacial flour would be deposited in enormous amounts, making the high and arid Patagonian tableland a huge glacial outwash plain where dust deflation can take place (Basile et al., 1997; Iriondo, 2000; Ridgwell and Watson, 2002; Sugden et al., 2009), considering that alluvial deposits are the most abundant present-day sources of dust (Prospero et al., 2002). In turn, the higher ice-surface altitude linked to PIS growth would not only further increase precipitation on the western side of the Andes by enhancing the orographic rise of moist Pacific air masses, but also favour foehn winds on the lee side of the Andes, which would intensify aridity and increase dust mobilization in the southern Pampas and Patagonia (Prieto, 1996; Hulton et al., 2002; Gaiero, 2007). Data suggest that the dust source area extended at least until $37^{\circ} \mathrm{S}$ during MIS 2 (Smith et al., 2003), and maybe even further north (Gaiero, 2007; Delmonte et al., 2010). The dust source area extended probably also further south and east of its present-day southern limit as a lowered sea-level would increase the Argentine continental shelf area (see section 4.3). Such a configuration may have allowed the outwash plains and rivers to extend further east, increasing the amount of fine sediment available for deflation (Sugden et al., 2009). Finally, the transport of dust to Antarctica was probably facilitated by a reduced glacial atmospheric washout (Lambert et al., 2008).

While this scenario would be valid for the coldest period of the last glacial period (i.e. MIS 4, late MIS 3 and MIS 2), the Southern Hemisphere was relatively warmer (EPICA Community members, 2004; Kaiser et al., 2005), the extension of Antarctic sea-ice was reduced (Crosta et al., 2004) and thus the SWW were probably restricted further south during early to mid-MIS 3. As a consequence, the size and height of the PIS were reduced, thus decreasing PIS glacial activity and dust production. Furthermore, increased humidity, soil moisture and vegetation cover east of the Andes due to reduced foehn winds would decrease dust deflation and transport. We suggest that climatic and oceanographic mechanisms that were operating during relatively cold and warm periods on orbital timescales were similarly active at millennial to multi-millennial timescales.

\subsection{Sea-level fluctuations and the Argentine shelf}

The long-term trends of the dust records from Antarctic ice cores are different from our records of PIS fluctuations. While a northward extension of the SWW during MIS 4, late MIS 3 and MIS 2 may have partly increased the amount of dust reaching Antarctica, sea-level fluctuations probably likewise played an important additional role in these longer timescales, too. Following Basile et al. (1997), the Argentine shelf sediments exposed by the sea-level drop during the last glacial have not been a source of atmospheric dust. However, as suggested by Gaiero (2007), the core-top continental shelf sediments analysed by Basile et al. (1997) may not represent the shelf composition of low sea-level periods. In the present-day, the Argentine shelf is composed mainly of sandy sediment (Guilderson et al., 2000), while most of the sediment delivered from Patagonia to the shelf is fine-grained, eolian material (Gaiero et al., 2003). This suggests that fine particles are removed from the shelf during sea-level high-stands. It is thus expected that sediment deposited during low sea-level periods had a dominant Patagonian dust signature.

As shown on Fig. 3, the high dust fluxes in Antarctica during MIS 4, late MIS 3 and MIS 2 occurred during sea-level low-stands. Data from the Argentine shelf suggest that the relative sea-level (RSL) was at $-150 \mathrm{~m}$ during MIS 2, corresponding to an eustatic sea-level of about $-105 \mathrm{~m}$ (Guilderson et al., 2000), while during early MIS 3 the RSL was close to or above $-80 \mathrm{~m}$ ( $-60 \mathrm{~m}$ eustatic level equivalence). As noticed by Wolff et al. (2006), the $-80 \mathrm{~m}$ isobaths on the Argentine shelf corresponds to a morphologic change between a relatively steep sloping shelf from 0 to $-80 \mathrm{~m}$ to a rather flat continental shelf from $-80 \mathrm{~m}$ to $-150 \mathrm{~m}$. Therefore, the larger increase of the exposed shelf area occurred during late MIS 3 and MIS 2, when the sea-level dropped between $-80 \mathrm{~m}$ and $-150 \mathrm{~m}$ 

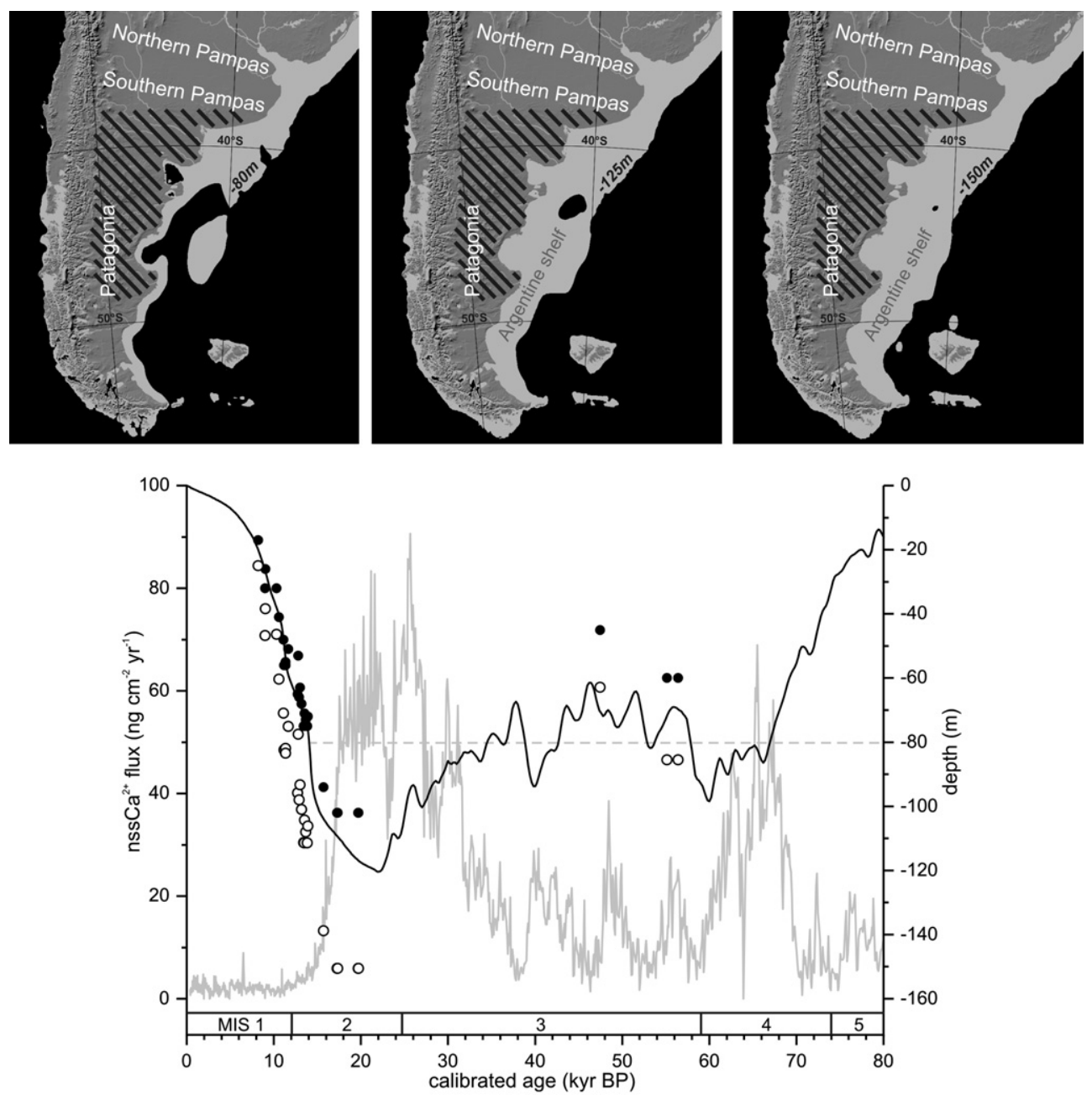

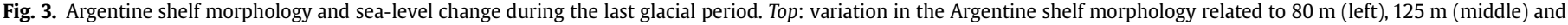

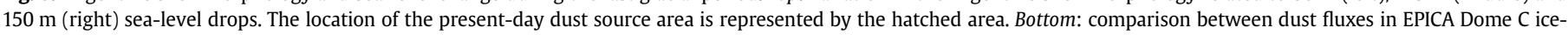

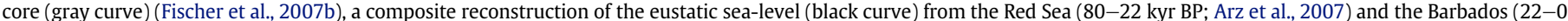

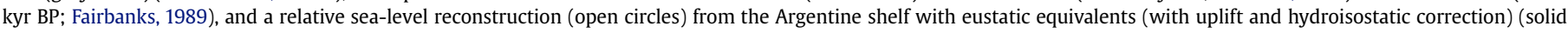

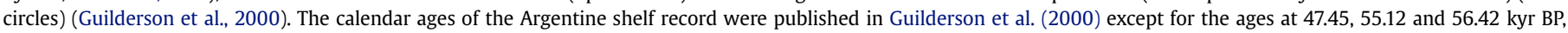
which we converted into calendar years using the "CalPal 2007 Hulu" calibration curve (www.calpal.de).

and the surface of Patagonia almost doubled (Iriondo, 2000). In contrast, the shelf area was probably much restricted during early MIS 3. Assuming that the relation between the eustatic sea-level record from the Red Sea (Arz et al., 2007) and the eustatic sea-level and RSL reconstructions from the Argentine shelf was constant, we can roughly estimate a $-125 \mathrm{~m}$ RSL during MIS 4 . The difference between the exposed shelf areas with $-150 \mathrm{~m}$ and $-125 \mathrm{~m}$ RSL is relatively small in comparison to the difference between $-80 \mathrm{~m}$ and $-150 \mathrm{~m}$ (Fig. 3). Thus, we argue that the effect of RSL changes between $-80 \mathrm{~m}$ and $-150 \mathrm{~m}$ on the Argentine shelf morphology during MIS 4 and 2 sea-level low-stands play an important role in explaining the long-term maxima of dust accumulation in Antarctica: a RSL stand below $-80 \mathrm{~m}$ would increase the exposed Argentine shelf, the extension of the outwash plains and rivers, and thus the amount of fine sediment available for deflation (Sugden et al., 2009). Ultimately, relatively shorter outwash rivers due to a lower sea-level drop during MIS 4 in comparison to late MIS 3 and MIS 2 may help to explain the relatively lower dust peak. Within dating uncertainties, dust increases during early MIS 4 and late MIS 3 seem to be synchronous to RSL lowering below $-80 \mathrm{~m}$. On the contrary, the dust drops at the end of MIS 4 and MIS 2 cannot be explained by sea-level rise as the $-80 \mathrm{~m}$ isobaths was submerged about 1-2 kyr later in both cases. Other mechanisms such as the formation of pro-glacial lakes trapping sediment (Sugden et al., 2009) or wind and humidity changes in the dust source area must have been involved to explain dust decrease after the pronounced long-term maxima during MIS 4 and MIS 2.

\subsection{Sea surface temperature influence on Northern Patagonian Ice Sheet variability}

As shown in the modelling study by Hulton et al. (2002), the NPIS variability is very sensitive to offshore SST changes. Lamy et al. (2004) and Kaiser et al. (2007) have shown the existence of a 0.5 to 0.7 kyr delay between SST warming and Fe decreases during MIS 4, late MIS 3 and MIS 2, which has been attributed to the inertia of the NPIS. However, no offset exists between SST cooling and Fe increases, i.e. NPIS growing phases. The offset is difficult to explain (Kaiser et al., 2007). The outlet glaciers of the present-day Northern and Southern Patagonian ice-fields are calving glaciers (Warren and Aniya, 1999), which are extremely sensitive to climate change (Meier and Post, 1987). Therefore, a rapid response to temperature changes can be likewise expected during the last glacial period. However, results from an ice flow model of the NPIS deglaciation 
forced by a re-scaled Vostok ice core temperature record into ELA shows a delay between the initiation of the temperature warming and ice-sheet melting (Hubbard et al., 2005). Afterwards, the rate of ice loss increases even more rapidly as the ice surface become lower in altitude. Therefore, ELA temperature-driven changes may explain part of the observed delay between SST warming and NPIS melting. Furthermore, considering that land terminating glaciers were onshore Site 1233 (Fig. 1C), rather than tidewater glaciers (which are sensitive to SST changes) air temperature warming could result temporarily in an increase in snowfall if the ice-sheet is sufficiently high, what may also partly explain the aforementioned delay.

\section{Conclusions}

Previous studies could establish a link between changes in the composition of the terrigenous supply at ODP Site 1233 and fluctuations in the extent of the NPIS (Lamy et al., 2004; Kaiser et al., 2007). Here, we show that NPIS millennial-scale variability is closely related to changes in Antarctic dust as recorded in EDC and EDML ice cores during most of the last glacial (70-18 kyr), assuming that NPIS advances and retreats are representative for the entire PIS fluctuations at this timescale. Colder SSTs and northward expanded SWW would favour PIS growth, an increased rock flour production, and deposition on outwash plains in the dust source areas located east of the southern Andes (southern Pampas and Patagonia). The increased height of the PIS further results in intensified foehn winds, which would in turn enhance aridity and dust mobilization. Furthermore, the transport of dust to Antarctica was facilitated by a reduced glacial atmospheric washout. Accordingly, PIS glacial retreats occurred during warmer intervals, when fine sediments are trapped in proglacial lakes and higher humidity reduces dust deflation in the dust source areas. Millennial-scale PIS fluctuations appear to lag SST changes in the southeast Pacific during MIS 4, late MIS 3 and MIS 2 , possibly due to ice dynamics. Finally, the long-term trends in Antarctic dust, which are not present in our records, may result from a broadening of the SWW and from the relation between sea-level fluctuations and the morphology of the exposed Argentine shelf. At the beginning of MIS 4 and MIS 2, sea-level drops below $-80 \mathrm{~m}$ were important for the long-term dust increases, while changes in the Patagonian dust source regions primarily controlled the early dust decrease during MIS 4/3 transition and Termination 1 that precedes the flooding of significant shelf areas above $-80 \mathrm{~m}$ present water depth.

\section{Acknowledgments}

We thank H.W. Arz for numerous interesting ideas and discussions on this study. Two anonymous reviewers are thanked for their constructive comments. This research used samples provided by the Ocean Drilling Program (ODP). The ODP is sponsored by the U.S. National Science Foundation (NSF) and participating countries under management of Joint Oceanographic Institutions (JOI), Inc.

\section{References}

Arz, H.W., Lamy, F., Ganopolski, A., Nowaczyk, N., Pätzold, J., 2007. Dominant Northern Hemisphere climate control over millennial-scale glacial sea-level variability. Quaternary Science Reviews 26, 312-321.

Basile, I., Grousset, F.E., Revel, M., Petit, J.R., Biscaye, P.E., Barkov, N.I., 1997. Patagonian origin of glacial dust deposited in East Antarctica (Vostok and Dome C) during glacial stages 2, 4 and 6. Earth and Planetary Science Letters 146, 573-589.

Blunier, T., Brook, E.J., 2001. Timing of millennial-scale climate change in Antarctica and Greenland during the last glacial period. Science 291, 109-112.
Broecker, W.S., 2000. Abrupt climate change: causal constraints provided by the paleoclimate record. Earth-Science Reviews 51, 137-154.

Cerveny, R., 1998. Present climates of South America. In: Hobbs, J.E. (Ed.), Climates of the Southern Continents: Present, Past and Future. Wiley, J. and Sons Ltd, West Sussex, England, pp. 107-135.

Crosta, X., Sturm, A., Armand, L., Pichon, J.J., 2004. Late Quaternary sea ice history in the Indian sector of the Southern Ocean as recorded by diatom assemblages. Marine Micropaleontology 50, 209-223.

Delmonte, B., Basile-Doelsch, I., Petit, J.R., Maggi, V., Revel-Rolland, M., Michard, A. Jagoutz, E., Grousset, F., 2004. Comparing the Epica and Vostok dust records during the last 220,000 years: stratigraphical correlation and provenance in glacial periods. Earth-Science Reviews 66, 63-87.

Delmonte, B., Andersson, P.S., Schöberg, H., Hansson, M., Petit, J.R., Delmas, R. Gaiero, D.M., Maggi, V., Frezzotti, M., 2010. Geographic provenance of aeolian dust in East Antarctica during Pleistocene glaciations: preliminary results from Talos Dome and comparison with East Antarctic and new Andean ice core data. Quaternary Science Reviews 29, 256-264.

DeMott, P.J., Sassen, K., Poellot, M.R., Baumgardner, D., Rogers, D.C., Brooks, S.D., Prenni, A.J., Kreidenweis, S.M., 2003. African dust aerosols as atmospheric ice nuclei. Geophysical Research Letters 20. doi:10.1029/2003GL017410.

Denton, G.H., Heusser, C.J., Lowell, T.V., Moreno, P.I., Andersen, B.G., Heusser, L.E., Schluchter, C., Marchant, D.R., 1999. Interhemispheric linkage of paleoclimate during the last glaciation. Geografiska Annaler Series a-Physical Geography $81 \mathrm{~A}, 107-153$.

Douglass, D.C., Singer, B.S., Kaplan, M.R., Mickelson, D.M., Caffee, M.W., 2006. Cosmogenic nuclide surface exposure dating of boulders on last-glacial and late-glacial moraines, Lago Buenos Aires, Argentina: Interpretive strategies and paleoclimate implications. Quaternary Geochronology 1 43-58.

EPICA community members, 2004. Eight glacial cycles from an Antarctic ice core. Nature 429, 623-628.

Fairbanks, R.G., 1989. A 17,000-year glacio-eustatic sea level record: influence of glacial melting rates on the Younger Dryas event and deep-ocean circulation. Nature 342, 637-642.

Fairbanks, R.G., Mortlock, R.A., Chiu, T.-C., Cao, L., Kaplan, A., Guilderson, T.P., Fairbanks, T.W., Bloom, A.L., Grootes, P.M., Nadeau, M.-J., 2005. Radiocarbon calibration curve spanning 0 to 50,000 years BP based on paired $230 \mathrm{Th} / 234 \mathrm{U} / 238 \mathrm{U}$ and $14 \mathrm{C}$ dates on pristine corals. Quaternary Science Reviews 24, 1781-1796.

Fischer, H., Siggaard-Andersen, M.-L., Ruth, U., Röthlisberger, R., Wolff, E., 2007a. Glacial/interglacial changes in mineral dust and sea-salt records in polar ice cores: sources, transport, and deposition. Reviews of Geophysics 45, RG1002,. doi:10.1029/2005RG000192.

Fischer, H., Fundel, F., Ruth, U., Twarloh, B., Wegner, A., Udisti, R., Becagli, S., Castellano, E., Morganti, A., Severi, M., Wolff, E., Littot, G., Röthlisberger, R. Mulvaney, R., Hutterli, M.A., Kaufmann, P., Federer, U., Lambert, F., Bigler, M., Hansson, M., Jonsell, U., de Angelis, M., Boutron, C., Siggaard-Andersen, M.-L. Steffensen, J.P., Barbante, C., Gaspari, V., Gabrielli, P., Wagenbach, D., 2007b. Reconstruction of millennial changes in dust emission, transport and regional sea ice coverage using the deep EPICA ice cores from the Atlantic and Indian Ocean sector of Antarctica. Earth and Planetary Science Letters 260, 340-354.

Gaiero, D.M., Probst, J.L., Depetris, P.J., Bidart, S.M., Leleyter, L., 2003. Iron and other transition metals in Patagonian riverborne and windborne materials: geochemical control and transport to the southern South Atlantic Ocean. Geochimica et Cosmochimica Acta 67, 3603-3623.

Gaiero, D.M., 2007. Dust provenance in Antarctic ice during glacial periods: from where in southern South America? Geophysical Research Letters 34, L17707. doi:10.1029/2007GL030520.

Gersonde, R., Crosta, X., Abelmann, A., Armand, L., 2005. Sea-surface temperature and sea ice distribution of the Southern Ocean at the EPILOG Last Glacial Maximum-a circum-Antarctic view based on siliceous microfossil records. Quaternary Science Reviews 24, 869-896.

Grousset, F.E., Biscaye, P.E., Revel, M., Petit, J.-R., Pye, K., Joussaume, S., Jouzel, J., 1992. Antarctic (Dome C) ice-core dust at $18 \mathrm{ky} \mathrm{BP:} \mathrm{Isotopic} \mathrm{constraints} \mathrm{on}$ origins. Earth and Planetary Science Letters 111, 175-182.

Guilderson, T., Burckle, L., Hemming, S., 2000. Late Pleistocene sea level variations derived from the Argentine Shelf. Geochemistry Geophysics Geosystems 1. doi:10.1029/2000GC000098.

Harrison, S.P., Kohfeld, K.E., Roelandt, C., Claquin, T., 2001. The role of dust in climate changes today, at the last glacial maximum and in the future. Earth-Science Reviews 54, 43-80.

Hollin, J.T., Schilling, D.H., 1981. Late Wisconsin-Weichselian mountain glaciers and small ice caps. In: Denton, G.H., Hughes, T.J. (Eds.), The Last Great Ice Sheets. Wiley, New York, pp. 179-220.

Hubbard, A., Hein, A.S., Kaplan, M.R., Hulton, N.R.J., Glasser, N., 2005. A modelling reconstruction of the last glacial maximum ice sheet and its deglaciation in the vicinity of the Northern Patagonian Icefield, South America. Geografiska Annaler, Series A: Physical Geography 87, 375-391.

Hulton, N.R.J., Purves, R.S., McCulloch, R.D., Sugden, D.E., Bentley, M.J., 2002. The Last Glacial Maximum and deglaciation in southern South America. Quaternary Science Reviews 21, 233-241.

Iriondo, M., 2000. Patagonian dust in Antarctica. Quaternary International 68-71, 83-86.

Kaiser, J., Lamy, F., Hebbeln, D., 2005. A 70-kyr sea surface temperature record off southern Chile (Ocean Drilling Program Site 1233). Paleoceanography 20. doi:10.1029/2005PA001146. 
Kaiser, J., Lamy, F., Arz, H.W., Hebbeln, D., 2007. Dynamics of the millennial-scale sea surface temperature and Patagonian Ice Sheet fluctuations in southern Chile during the last $70 \mathrm{kyr}$ (ODP Site 1233). Quaternary International 161, 77-89.

Kaiser, J., Schefuß, E., Lamy, F., Mohtadi, M., Hebbeln, D., 2008. Glacial to Holocene changes in sea surface temperature and coastal vegetation in north central Chile: high versus low latitude forcing. Quaternary Science Reviews 27, 2064-2075

Kerr, A., Sugden, D., 1994. The sensitivity of the south chilean snowline to climatic change. Climatic Change 28, 255-272.

Kalnay, E., Kanamitsu, M., Kistler, R., Collins, W., Deaven, D., Gandin, L., Iredell, M., Saha, S., White, G., Woollen, J., Zhu, Y., Leetmaa, A., Reynolds, B., Chelliah, M., Ebisuzaki, W., Higgins, W., Janowiak, J., Mo, K.C., Ropelewski, C., Wang, J., Jenne, R., Joseph, D., 1996. The NCEP/NCAR 40-year reanalysis project. Bulletin of the American Meteorological Society 77, 437-470.

Kaplan, M.R., Fogwill, C.J., Sugden, D.E., Hulton, N.R.J., Kubik, P.W., Freeman, S.P.H.T. 2008. Southern Patagonian glacial chronology for the Last Glacial period and implications for Southern Ocean climate. Quaternary Science Reviews 27, 284-294.

Krinner, G., Genthon, C., 2003. Tropospheric transport of continental tracers towards Antarctica under varying climatic conditions. Tellus B 55, 54-70.

Lambert, F., Delmonte, B., Petit, J.R., Bigler, M., Kaufmann, P.R., Hutterli, M.A., Stocker, T.F., Ruth, U., Steffensen, J.P., Maggi, V., 2008. Dust-climate couplings over the past 800,000 years from the EPICA Dome C ice core. Nature 452 , $616-619$

Lamy, F., Hebbeln, D., Wefer, G., 1999. High-resolution marine record of climatic change in mid- latitude Chile during the last 28,000 years based on terrigenous sediment parameters. Quaternary Research 51, 83-93.

Lamy, F., Kaiser, J., Ninnemann, U., Hebbeln, D., Arz, H., Stoner, J., 2004. Antarctic timing of surface water changes off Chile and Patagonian Ice Sheet response. Science 304, 1959-1962.

Lamy, F., Kaiser, J., Arz, H.W., Hebbeln, D., Ninnemann, U., Timm, O., Timmermann, A. Toggweiler, J.R., 2007. Modulation of the bipolar seesaw in the Southeast Pacific during Termination 1. Earth and Planetary Science Letters 259, 400-413.

Lund, S., Stoner, J., Lamy, F., 2007. Late Quaternary paleomagnetic secular variations records and chronostratigraphy from ODF Sites 1233 and 1234. In: Mix, A. Tiedeman, R., Blum, P. (Eds.), Proceedings of the Ocean Drilling Project. Scientific Results 202. Ocean Drilling Program, College Station, TX, pp. 200-210.

Mahowald, N.M., Kohfeld, K., Hansson, M., Balkanski, Y., Harrison, S., Prentice, I. Schulz, M., Rodhe, H., 1999. Dust sources and deposition during the last glacial maximum and current climate: a comparison of model results with paleodata from ice cores and marine sediments. Journal of Geophysical Research 104 15895-15916.

Mahowald, N.M., Kiehl, L.M., 2003. Mineral aerosol and cloud interactions. Geophysical Research Letters 30. doi:10.1029/2002GL016762.

Markgraf, V., Dodson, J.R., Kershaw, P.A., McGlone, M.S., Nicholls, N., 1992. Evolution of late Pleistocene and Holocene climates in the circum-South Pacific land areas. Climate Dynamics 6, 193-211.

Martin, J.H., 1990. Glacial-Interglacial $\mathrm{CO}_{2}$ change: the iron hypothesis. Paleoceanography $5,1-13$.

McCulloch, R.D., Bentley, M.J., Purves, R.S., Hulton, N.R.J., Sugden, D.E., Clapperton, C. M., 2000. Climatic inferences from glacial and palaeoecological evidence at the last glacial termination, southern South America. Journal of Quaternary Sciences 15, 409-417.

McCulloch, R.D., Fogwill, C.J., Sugden, D.E., Bentley, M.J., Kubik, P.W., 2005. Chronology of the Last Deglaciation in central Strait of Magellan and Bahia Inutil, southernmost South America. Geografiska Annaler, Series A: Physical Geography $87,289-312$

Meier, M.F., Post, A., 1987. Fast Tidewater Glaciers. Journal of Geophysical Research 92, 9051-9058.

Mix, A.C., Tiedemann, R., Blum, P., 2003. Leg 202 Summary. Ocean Drilling Program, College Station, TX

Mollenhauer, G., Kienast, M., Lamy, F., Meggers, H., Schneider, R.R., Hayes, J.M. Eglinton, T.I. 2005. An evaluation of C-14 age relationships between $\mathrm{CO}^{-}$ occurring foraminifera, alkenones, and total organic carbon in continenta margin sediments. Paleoceanography 20, PA1016,. doi:10.1029/2004PA001103.

Mora, G. Martinez, J.I, 2005. Sedimentary metal ratios in the Colombia Basin as indicators for water balance change in northern South America during the past 400,000 years. Paleoceanography 20, PA4013,. doi:10.1029/2005PA001132.

Moreno, P.I., Lowell, T.V., Jacobson, G.L., Denton, G.H., 1999. Abrupt vegetation and climate changes during the last glacial maximum and last termination in the Chilean Lake District: A case study from Canal de la Puntilla (41 $\left.{ }^{\circ} \mathrm{S}\right)$. Geografiska Annaler, Series A: Physical Geography 81A, 285-311.

Murray, R.W., Leinen, M. 1993. Chemical transport to the seafloor of the equatoria Pacific Ocean across a latitudinal transect at $135^{\circ} \mathrm{W}$ : Tracking sedimentary major, trace, and rare earth element fluxes at the Equator and the Intertropical Convergence Zone. Geochimica et Cosmochimica Acta 57, 4141-4163.

Okin, G.S., Mahowald, N.M., Chadwick, O.A., Artaxo, P., 2004. Impact of desert on the biogeochemistry of phosphorus in terrestrial ecosystems. Global Biogeochemical Cycles 18. doi:10.1029/2003GB002145.

Parrenin, F., Barnola, J.-M., Beer, J., Blunier, T., Castellano, E., Chappellaz, J., Dreyfus, G., Fischer, H., Fujita, S., Jouzel, J., Kawamura, K., Lemieux-Dudon, B., Loulergue, L., Masson-Delmotte, V., Narcisi, B., Petit, J.-R., Raisbeck, G., Raynaud, D., Ruth, U., Schwander, J., Severi, M., Spahni, R., Steffensen, J.P. Svensson, A., Udisti, R., Waelbroeck, C., Wolff, E., 2007. The EDC3 chronology for the EPICA Dome C ice core. Climate of the Past 3, 485-497.
Penner, J.E., Andreae, M., Annegarn, H., Barrie, L., Feichter, J., Co-authors, 2001. Aerosols, their direct and indirect effects. In: Houghton, J.T., Ding, Y., Griggs, D.J., Noguer, M., van der Linden, P.J., Xiaoxu, D. (Eds.), Climate Change 2001: The Scientific Basis, Contribution of Working Group I to the Third Assessment Report of the Intergovernmental Panel on Climate Change (IPCC). Cambridge University Press, Cambridge, pp. 289-348.

Prahl, F.G., Muehhausen, L.A., Zahnle, D.L., 1988. Further evaluation of long-chain alkenones as indicators of paleoceanographic conditions. Geochimica et Cosmochimica Acta 52, 2303-2310.

Prieto, A.R., 1996. Late Quaternary Vegetational and Climatic Changes in the Pampa Grassland of Argentina. Quaternary Research 45, 73-88.

Prospero, J.M., Ginoux, P., Torres, O., Nicholson, S.E., Gill, T.E., 2002. Environmental characterization of global sources of atmospheric soil dust identified with the nimbus 7 total ozone mapping spectrometer (TOMS) absorbing aerosol product. Reviews of Geophysics 40, 1002,. doi:10.1029/2000RG000095.

Rea, D.K., 1994. The paleoclimatic record provided by eolian deposition in the deep sea: the geologic history of wind. Reviews of Geophysics 32, 159-195.

Reimer, P.J., Baillie, M.G.L., Bard, E., Bayliss, A., Beck, J.W., Blackwell, P.G., Buck, C.E., Burr, G.S., Cutler, K.B., Damon, P.E., Edwards, R.L., Fairbanks, R.G., Friedrich, M., Guilderson, T.P., Herring, C., Hughen, K.A., Kromer, B., McCormac, F.G., Manning, S.W., Ramsey, C.B., Reimer, P.J., Reimer, R.W., Remmele, S., Southon, J. R., Stuiver, M., Talamo, S., Taylor, F.W., van der Plicht, J., Weyhenmeyer, C.E., 2004. INTCAL04 Terrestrial radiocarbon age calibration, 0-26 cal kyr BP. Radiocarbon 46, 1029-1058.

Reijmer, C.H., van den Broeke, M.R., Scheele, M.P., 2002. Air parcel trajectories and snowfall related to five deep drilling locations in Antarctica based on the ERA15 Dataset. Journal of Climate 15, 1957-1968.

Ridgwell, A.J., 2002. Dust in the Earth system: the biogeochemical linking of land, air and sea. Philosophical Transactions of the Royal Society London 360, 2905-2924. doi:10.1098/rsta.2002.1096.

Ridgwell, A.J., Watson, A., 2002. Feedback between aeolian dust, climate, and atmospheric CO2 in glacial time. Paleoceanography 17, 1059,. doi:10.1029/ 2001PA000729.

Röthlisberger, R., Mulvaney, R., Wolff, E.W., Hutterli, M.A., Bigler, M., Sommer, S, Jouzel, J., 2002. Dust and sea salt variability in central East Antarctica (Dome C) over the last 45 kyrs and its implications for southern high-latitude climate. Geophysical Research Letters 29, 1963,. doi:10.1029/2002GL015186.

Ruth, U., Wagenbach, D., Steffensen, J.P., Bigler, M., 2003. Continuous record of microparticle concentration and size distribution in the central Greenland NGRIP ice core during the last glacial period. Journal of Geophysical Research 108, D34098,. doi:10.1029/2002JD002376.

Ruth, U., Barnola, J.-M., Beer, J., Bigler, M., Blunier, T., Castellano, E., Fischer, H., Fundel, F., Huybrechts, P., Kaufmann, P., Kipfstuhl, S., Lambrecht, A., Morganti, A., Oerter, H., 2007. EDML1: A chronology for the EDML ice core, Antarctica, over the last 150000 years. Climate of the Past 3, 475-484.

Severi, M., Becagli, S., Castellano, E., Morganti, A., Traversi, R., Udisti, R., Ruth, U., Fischer, H., Huybrechts, P., Wolff, E., Parrenin, F., Kaufmann, P., Lambert, F., Steffensen, J.P., 2007. Synchronisation of the EDML and EDC ice cores for the last 52 kyr by volcanic signature matching. Climate of the Past 3, 367-374.

Smith, J., Vance, D., Kemp, R.A., Archer, C., Toms, P., King, M., Zárate, M., 2003. Isotopic constraints on the source of Argentinian loess - with implications for atmospheric circulation and the provenance of Antarctic dust during recent glacial maxima. Earth and Planetary Science Letters 212, 181-196.

Steffensen, J.P., 1997. The size distribution of microparticles from selected segments of the Greenland Ice Core Project ice core representing different climatic periods. Journal of Geophysical Research 102, 26,755-26,763.

Stuut, J.B.W., Lamy, F., 2004. Climate variability at the southern boundaries of the Namib (southwestern Africa) and Atacama (northern Chile) coastal deserts during the last 120,000 yr. Quaternary Research 62, 301-309.

Sugden, D.E., McCulloch, R.D., Bory, A.J.M., Hein, A.S., 2009. Influence of Patagonian glaciers on Antarctic dust deposition during the last glacial period. Nature Geoscience 2, 281-285.

Svensson, A., Andersen, K.K., Bigler, M., Clausen, H.B., Dahl-Jensen, D., Davies, S.M., Johnsen, S.J., Muscheler, R., Rasmussen, S.O., Röthlisberger, R., Peder Steffensen, J., Vinther, B.M., 2006. The Greenland Ice Core Chronology 2005, 15-42 ka. Part 2: comparison to other records. Quaternary Science Reviews 25, 3258-3267.

Warren, C., Aniya, M., 1999. The calving glaciers of southern South America. Global and Planetary Change 22, 59-77.

Werner, M., Tegen, I., Harrison, S.P., Kohfeld, K.E., Prentice, I.C., Balkanski, Y., Rodhe, H., Roelandt, C., 2002. Seasonal and interannual variability of the mineral dust cycle under present and glacial climate conditions. Journal of Geophysical Research 107, 4744,. doi:10.1029/2002JD002365.

Winckler, G., Anderson, R.F., Fleisher, M.Q., McGee, D., Mahowald, N.M., 2008. Covariant Glacial-Interglacial Dust Fluxes in the Equatorial Pacific and Antarctica. Science 320, 93-96.

Winckler, G., Fischer, H., 2009. 30,000 Years of cosmic dust in Antarctic Ice. Science 313,491

Wolff, E.W., Fischer, H., Fundel, F., Ruth, U., Twarloh, B., Littot, G.C., Mulvaney, R., Rothlisberger, R., de Angelis, M., Boutron, C.F., Hansson, M., Jonsell, U., Hutterli, M.A., Lambert, F., Kaufmann, P., Stauffer, B., Stocker, T.F., Steffensen, J.P., Bigler, M., Siggaard-Andersen, M.L., Udisti, R., Becagli, S., Castellano, E., Severi, M., Wagenbach, D., Barbante, C., Gabrielli, P., Gaspari, V., 2006. Southern Ocean sea-ice extent, productivity and iron flux over the past eight glacial cycles. Nature 449, 748-758. 